\title{
Düşünme Stillerine Göre Farklılaştırılmış Öğretim Etkinliklerine İlişkin Öğrenci Görüşleri*
}

\section{Opinions of Students about Thinking-Style-Based Differentiated Instruction

\author{
Selda ÖZER ${ }^{* *}$ \\ Ercan YILMAZ
}

\begin{abstract}
Öz. Bu çalışmanın amacı, önlisans düzeyinde mesleki yabancı dil dersi kapsamında "Rezervasyon Yapma" ve "Otele Giriş-Çıkış İşlemleri" üniteleri için öğrencilerin düşünme stillerine göre tasarlanan farklılaştırılmış öğretim etkinlikleri hakkında öğrenci görüşlerini belirlemektir. Araştırma, nitel araştırma yöntemlerinden durum çalışmasına göre desenlenmiş ve veri toplamak amacıyla görüşme formu kullanılmıştır. Araştırma; 2014-2015 bahar yarıyılında, bir Meslek Yüksekokulu'nun Turizm ve Otel İşletmeciliği programında öğrenim gören 25 ikinci sınıf öğrencisi ile yürütülmüştür. Çalışmada, öğrencilerin düşünme stillerinin işlev, düzey ve kapsam boyutları ve bu boyutların 7 alt boyutu dikkate alınmıştır. Farklılaştırma süreç boyutunda yapılmıştır. Süreç farklılaştırıırken, istasyon, karmaşık öğretim, yörünge çalışmaları, merkezler, giriş noktaları ve öğrenme sözleşmeleri stratejilerinden faydalanılmıştır. Uygulama süreci, 42 ders saatinde yürütülmüştür. Uygulama sürecinin ardından, öğrenci görüşleri açık uçlu görüşme formu aracılığıyla elde edilmiştir. Araştırmadan elde edilen sonuçlar, düşünme stillerine göre farklılaştırılmış öğretim etkinlikleri hakkında öğrenci görüşlerinin genel olarak olumlu olduğunu ve bu etkinliklerin öğrencilerin derse olan ilgilerini ve derse katılımlarını arttırdığını göstermiştir.
\end{abstract}

Anahtar Kelimeler: Düşünme stilleri, farklılaştırılmış öğretim, mesleki yabancı dil dersi, öğrenci görüşleri.

\begin{abstract}
The purpose of the study was to examine opinions of students about thinking-style-based differentiated instruction designed for the units "Booking a Hotel Room" and "Check-in and Check-out in a Hotel" in scope of Vocational Foreign Language Course at associate degree. Qualitative research method, case study and interview form were used in the study. The study was carried out with 25 students studying at Tourism and Hotel Management Program and taking Vocational Foreign Language Course at 2014-2015 spring semester at a Vocational College. Functions, levels and scopes of thinking styles were taken into consideration. Process was differentiated in the study using stations, complex instruction, orbital studies, learning centers, entry points and learning contracts. After the experimental study, lasting 42 periods, the students were asked to express their opinions about the process. The data were collected using a standardized open-ended interview form. The results of the research showed that the opinions of the students about thinkingstyle-based differentiated instruction were positive and that the activities increased their interests and participation in the course.
\end{abstract}

Keywords: Thinking styles, differentiated instruction, vocational foreign language course, opinions of students.

\section{Toplumsal Mesaj.}

Bu çalışmanın amacı, önlisans düzeyinde mesleki yabancı dil dersi kapsamında

"Rezervasyon Yapma" ve "Otele Giriş-Çıkış İşlemleri" üniteleri için öğrencilerin düşünme stillerine göre tasarlanan farklılaştırılmış öğretim etkinlikleri hakkında öğrenci görüşlerini belirlemektir.

\section{Public Interest Statement.}

The purpose of the study was to examine opinions of students about thinking-stylebased differentiated instruction designed for the units "Booking a Hotel Room" and "Check-in and Check-out in a Hotel" in scope of Vocational Foreign Language Course at associate degree.

\footnotetext{
* Bu makale, birinci yazarın ikinci yazar danışmanlığında tamamlanarak kabul edilen “Düşünme Stillerine Göre Farklılaştırılmış Öğretim Etkinliklerinin Öğrencilerin Erişilerine, Mesleki Yabancı Dil Dersine Yönelik Tutumlarına ve Öğrenilenlerin Kalıcılığına Etkisi" başııkı doktora tezinden üretilmiş ve Muğla Sıtkı Koçman Üniversitesi tarafından 31 Mayıs-3 Haziran 2016 tarihleri arasında Muğla'da düzenlenen 3. Uluslararası Avrasya Eğitim Araştırmaları Kongresi (IIIrd International Eurasian Educational Research Congress)'nde sözlü bildiri olarak sunulmuştur.

** Orcid ID: https://orcid.org/0000-0003-2648-9150, Öğr.Gör. Dr., Nevşehir Hacı Bektaş Veli Üniversitesi, Yabancı Diller Yüksekokulu, sozer@nevsehir.edu.tr

*** Orcid ID: https://orcid.org/0000-0003-4702-1688, Prof. Dr., Necmettin Erbakan Üniversitesi, Ahmet Keleşoğlu Eğitim Fakültesi, Eğitim Bilimleri Bölümü, ercanyilmaz70@gmail.com
} 


\section{GíRiş}

Düşünme stilleri, bireyin dünya ile ilişkisinde, onu algılamasında, hedeflediği amaçlara ulaşmasında ve problem çözmesinde, geliştirdiği bilgi işleme yöntemidir (Sternberg, 1997; Sternberg ve Zhang, 2005; Zhang ve Sternberg, 2000). Düşünme stilleri, işlev, biçim, düzey, kapsam ve eğilim olarak 5 boyutta değerlendirilir. Her bir boyut kendi içinde farklı alt boyutlardan oluşmaktadır. Düşünme stilleri ve temel özellikleri Tablo 1'de özetlenmiştir.

Tablo 1. Düşünme stilleri ve temel özellikleri

\begin{tabular}{|c|c|c|}
\hline Boyut & Alt boyut & Temel özellikleri \\
\hline \multirow{7}{*}{ İşlevler } & Yasayapıcı & Yenilikçi, yaratıcı, fikir üreten. \\
\hline & & Kendi kurallarını oluşturmaktan hoşlanan. \\
\hline & & Önceden yapılandırılmamış problemleri tercih eden. \\
\hline & Yürütmeci & Uyumlu, düzenli, verilen talimatları izleyen. \\
\hline & & Hazır ve planlanmış olarak verilen problemleri tercih eden. \\
\hline & Yargılayıсı & Yargılayan, değerlendiren, görüş belirten. \\
\hline & & Çözümleme ve eleştiri yapabileceği problemleri tercih eden. \\
\hline \multirow{11}{*}{ Biçimler } & Tekerkçi & Aynı anda tek amaca ve işe odaklanan. \\
\hline & & İlgisini çeken konularla motive olan. \\
\hline & & Aklına koyduklarını yapan, azimli ve gayretli. \\
\hline & Aşamacı & Çok işi aynı anda, öncelik belirleyerek yapan. \\
\hline & & Problem çözme ve karar vermede sistemli ve düzenli. \\
\hline & & Zaman ve kaynakları dengeli kullanmada başarılı. \\
\hline & Çokerkçi & Çok işi aynı anda, öncelikleri belirleyemeden yapan. \\
\hline & & Zaman ve kaynakları dengeli kullanmada güçlük çeken. \\
\hline & Anarşik & İşlere rastgele yaklaşan, sistemlerden kaçınan. \\
\hline & & Antisosyal davranış gösterme riski olan. \\
\hline & & Uyum sağlayamayan ama bazen yaratıcı. \\
\hline \multirow{4}{*}{ Düzeyler } & Bütünsel & Soyut düşüncelerle, genel çerçeveyle uğraşan. \\
\hline & & Ayrıntıları görmezden gelen. \\
\hline & Ayrıntısal & Somut düşüncelerle, ayrıntılarla uğraşan. \\
\hline & & Bazen bütünü gözden kaçıran. \\
\hline \multirow{5}{*}{ Kapsam } & İçedönük & Bağımsız, kendine yeten, iletişimden kaçınan. \\
\hline & & İçine kapanık, görev odaklı, yalnız çalışmayı seven. \\
\hline & & Bazen mesafeli ve sosyal açıdan daha duyarsız. \\
\hline & Dışadönük & Başkalarıyla çalışan, sosyal olan, bağımlı olan. \\
\hline & & İnsana odaklı, cana yakın, sosyal açıdan daha duyarlı. \\
\hline \multirow{6}{*}{ Eğilimler } & Yenilikçi & Yenilikçi, geleneğe karşı çıkan, hayalci. \\
\hline & & Bir miktar belirsizlik içeren durumları seven. \\
\hline & & Heyecan peşinde koşan, çabuk sıkılan. \\
\hline & Tutucu & Geleneksel, denenmişi tercih eden, gerçekçi. \\
\hline & & Belirsizlik içeren durumlardan kaçınan. \\
\hline & & Planlı ve önceden kestirilebilir ortamları seven. \\
\hline
\end{tabular}

Kaynak: Fer (2005); Sternberg (2009). 
Farklılaştırılmış öğretim, Tomlinson (1999)'a göre, öğrencilerin sunulan içeriği keşfetmeleri için, çeşitli yolların kullanılı̆̆ı, etkinliklerin ve sürecin öğrencilerin anlamlı öğrenmelerine yönelik yapıldığı ve öğrencilerin öğrendiklerini sergilemek için seçimlerini yapabildikleri bir öğrenme yaşantısıdır. Öğretmenler, öğrencilerin hazırbulunuşluk, ilgi ve öğrenme profillerine göre içerik, süreç veya ürünü farkılış̧tırabilirler. Süreç farklılaştırılırken değişik öğretim stratejilerinden yararlanılabilir. İstasyonlar, öğrencilerin aynı anda çeşitli öğrenme etkinliklerini gerçekleștirebilecekleri merkezlerdir. Karmaşık öğretim; akademik, kültürel ve dilsel yönden birbirinden çok farklı olan öğrencilerin bulunduğu sınıflardaki çeşitliliğe hitap etmek için geliştirilmiş bir stratejidir. Yörünge çalışmaları, proje yönteminin bireysel uygulanan bir şekli olarak tanımlanabilir. Merkezlerde aynı konunun farklı yollarla öğrenilmesi amaçlanmaktadır. Öğrenme merkezleri, yeni bir konunun öğretilmesi veya öğrenilmiş bir konunun pekiştirilmesi amacıyla, sınıfların bir köşesinde hazırlanan etkinlik ve malzemelerin bulundukları alanlardır. Giriş noktaları çoklu zekâ kuramına dayanmaktadır. Öğretmen, öğrenci intiyaçlarına göre farklı giriş noktalarından faydalanabilir. Anlatımsal giriş noktası, üzerinde çalışılan konu ya da kavramla ilgili bir hikaye anlatılması veya anlatım yapılmasını ifade etmektedir. Temel giriş noktası, konunun ya da kavramın temelini oluşturan felsefenin, kelime veya terimlerin incelenmesini içermektedir. Deneyimsel giriş noktası, öğrencilerin doğrudan konu veya kavramı temsil eden malzemelerle çalışmasını, uygulamalı yaklaşımın kullanımasını kapsamaktadır. Bu malzemeler, aynı zamanda öğrencilerin bireysel deneyimleriyle ilişkilendirilmelidir. Öğrenme sözleşmeleri, öğrencilerin önemli beceri ve kavramları edinmeleri için, onlara bazı özgürlükler veren bir anlaşmadır. Öğrencilerin öğretmeöğrenme sürecine aktif katııılarını artırmak, onlara bağımsız çalışma alışkanlığı kazandırmak ve kendi öğrenmelerinden sorumlu olmalarını sağlamak amacıyla kullanılan bir stratejidir (Tomlinson, 1999; Tomlinson, 2001).

Alan yazın incelendiğinde, düşünme stilleri ile ilgili çok sayıda çalışma yapıldığı görülmektedir. Düşünme stilleri ile öğrenme stilleri (Clarke, Lesh, Trocchio ve Wolman, 2010; Subaşı, 2010), akademik başarı (Lau, 2014; Sökmen, 2013; Tunçer, 2013), eleştirel düşünme (Zhang, 2003), öğretim yöntem ve yaklaşımları (Duman ve Çelik, 2011), öğretim stilleri (Zhang, 2008 ), tutum (Negari ve Solaymani, 2013), kültürel uyum (Yıldızlar, 2010), problem çözme becerileri (Düzgün, 2011), çoklu zeka türleri (Beceren ve Özdemir, 2010), bilişüstü stratejiler (Sökmen, 2013), başarı motivasyonu (Nikoupoor, Alam ve Tajbakhsh, 2012), tükenmişlik düzeyi (Uğurlu, 2012), matematik öğretim kaygısı (Altundal, 2013), dil öğrenme stratejileri (Ahmadi, Gorjian ve Pazhakh, 2014), yabancı dilde bağlamdan kelimenin anlamını tahmin etme başarısı (Önkuzu, 2013), karar verme stilleri (Öztabak, 2013), bilişsel öğrenme ve örtük öğrenme (Xie, Gao ve King, 2013), öğrenme ortamları (Fan ve Zhang, 2014), duygusal zeka (Karabulut, 2014) ve matematik öz- yeterlikleri (Şenay, 2014) arasındaki ilişkileri inceleyen çalışmalar olduğu tespit edilmiştir. Alanyazında, düşünme stillerinin demografik özellikler ve farklı değişkenler açısından farklılaşıp farkılış̧madığını inceleyen araştırmalar da mevcuttur (Canbolat, 2011; Çitil, 2011; Demir ve Osmanoğlu, 2013; Emir, 2011; Esmer, 2013; Özbaş, 2013; Turki, 2012; Zhu, 2013; Zhu ve Zhang, 2011). Düşünme stillerinin akademik başarıyı (Fan, Zhang ve Watkins, 2010; Richmond ve Conrad, 2012), kişilerarası davranışları (Yu ve Chen, 2012) ve bilişüstü farkındalığı (Khin ve Win, 2012; Zhang, 2010) yordama gücü de bazı çalışmalarda incelenmiştir. Tüm bu çalışmalarda, lise ve üniversite öğrencilerinin, öğretmen adaylarının, öğretmenlerin ve yöneticilerin düşünme stilleri belirlenmeye, düşünme stillerinin bazı değişkenler açısından farklılık gösterip göstermediği tespit edilmeye ve düşünme stillerinin farklı kavramlarla olan ilişkileri ortaya konmaya çalışılmıştır.

Bununla birlikte, düşünme stilleri ile ilgili yapılmış deneysel çalışma sayısı ise oldukça azdır. Bir çalışmada, geleneksel öğretim ve çoklu ortamın kullanıldığı Genel Psikoloji dersinde üniversite öğrencilerinin düşünme stillerinin çalışma sonrasında nasıl değişiklik gösterdiği incelenmiştir. Geleneksel öğretimin uygulandığı grupta aşamacı, yürütmeci, tutucu ve tekerkçi düşünme stillerinin kullanımı artarken, ayrıntısal düşünme stili kullanımı azalmıştır. Çoklu ortamın uygulandığı grupta, yargılayıcı ve yenilikçi düşünme stillerinin kullanımı artarken, yasayapıcı düşünme stilinin kullanımı azalmıştır (Fan, 2012). Başka bir araştırmada, öğrencilerin düşünme 
stillerinin kapsam boyutu dikkate alınarak içedönük ve dışadönük öğrencilere göre farklı çevrimiçi etkileşim tasarımları düzenlenmiş ve bu öğretim tasarımının akademik başarı ve güdülenme üzerindeki etkileri araştııımıştır. Araştırma sonunda, düzenlenen farklı etkileşim tasarımlarının öğrencilerin süreçteki akademik başarılarında anlamlı bir fark yarattığl; dışadönük düşünme stiline uygun etkileşim tasarımının sunulduğu öğrenme ortamında çalışan öğrencilerin daha başarılı oldukları; düşünme stillerine göre hazırlanan farklı çevrimiçi etkileşim tasarımlarının, öğrencilerin sonuç değerlendirmeden aldıkları akademik başarı puanlarında ve güdülenme düzeylerinde anlamlı fark yaratmadığı sonucuna varılmıştır (Güneş ve Yalın, 2017). Bahsi geçen çalışmalarda, öğrencilerin görüşlerine başvurulmamıştır.

Farklılaştırılmış öğretim ile ilgili yapılmış çalışmalar incelendiğinde, değişik ders ve öğretim kademelerinde farklılaştııılmış öğretim stratejilerinin uygulandığı tespit edilmiştir. Beler (2010) katlı öğretim stratejisini Hayat Bilgisi dersinde; Karadağ ve Yaşar (2010) Türkçe dersinde uygulamıştır. Okuma çemberi stratejisinin okuduğunu anlama üzerindeki etkisi incelenmiştir (Avcl ve Yüksel, 2011; Cummings, 2011). Bradfield (2012) esnek gruplama, öğrenme merkezleri, okuma yazma istasyonları, görev kartları ve küpleme stratejilerini kullanmıştır. En çok kullanılan farklılaştırıımış öğretim stratejinin istasyon olduğu görülmüştür (Mergen, 2011; Yüksel ve Avcı, 2011; Batdı ve Semerci, 2012; Güçlüer ve Kesercioğlu, 2012; Özyaprak, 2012; Şaldırak, 2012; Demir, 2013; Taş, 2013; James, 2013; Konstantinou-Katzi ve diğ., 2013; Maxey, 2013; Sayı, 2013; Üşenti, 2013; Çalıkoğlu, 2014; Umar, 2014; Avcı, 2015; Yılmaz, 2015). Bu çalışmalarda, öğrenci başarısının ve akademik benliğin, derse karşı ilgi, tutum ve motivasyonun, öz-yeterlik algısı ve bilişüstü becerilerin arttığı, fakat kaygı düzeyinin değişmediği sonuçlarına ulaşılmıştır.

Deneysel çalışmaların ardından bazı araştırmalarda öğrenci ve öğretmen görüşleri de incelenmiştir. Sondergeld ve Schultz (2008) tarafından yapılan araştırmada, katlı öğretimin etkisi incelenmiş ve öğrencilerle ve öğretmenlerle bireysel görüşmeler yapılımıştır. Öğrenciler katlı öğretimi eğlenceli bulmuşlar; seçme fırsatları verilmesinden hoşlanmışlar, konuyu kolay anladıklarını belirtmişlerdir. Özellikle, kendi hızlarında öğrendiklerinden öğrenmelerinin daha kolay olduğunu ifade etmişlerdir. Öğretmenler ise, bu şekilde bir tasarım hazırlamanın çok zor olduğunu, ancak uygulamanın eğlenceli ve kolay olduğunu belirtmişlerdir. Avcı ve diğ.(2009), istasyon ve ilgi merkezlerinin öğrencileri bilişsel ve duyuşsal açıdan nasıl etkilediğini incelenmişlerdir. Uygulama esnasında gözlemler, öğrencilerle odak grup görüşmesi ve sınıf öğretmeni ile görüşmeler yapılmıştır. Araştırma sonunda, farklılaştırılmış öğretimin öğrencilerin öğrenmelerini olumlu etkilediği, öğrencilerin derse olan ilgilerinin arttığı ve arkadaşlık ilişkilerinin gelişimine yardımcı olduğu sonucuna varılmıştır. Bir başka çalışmada, farklılaştırılmış öğretimin öğrenciler arasında dayanışmayı arttırdığı, iletişim becerilerini geliştirdiği, grup arkadaşlarıyla etkileşimi arttırdığı, öğrencilerin problem çözme, yaratıcı düşünme gibi üst düzey düşünme becerilerinin gelişimine katkı sağladığı ortaya çıkmıştır (Samms, 2009). Farkılış̧tııımış öğretim, öğrencilerin etkinliklere etkin bir biçimde katılmalarında, bireysel ve grup çalışması becerilerini geliştirmelerinde, öğretmene bağımlılıklarının azalmasında, bağımsız çalışma alışkanlığı kazanmalarında, Türkçe dersine yönelik olumlu tutumlar geliştirmelerinde, eleştirel düşünme, problem çözme, sorgulayıcı düşünme ve yaratıcı düşünme gibi üst düzey düşünme becerilerini geliştirmelerinde, paylaşım, empati kurma, farklı fikirlere saygı duyma konusunda ve kendi öğrenmelerine ilişkin bir farkındalık geliştirerek öğrenme stillerini keşfetmelerinde etkili olmuştur (Karadağ ve Yaşar, 2010).

Özel amaçlı İngilizcenin bir parçası olarak değerlendirilen mesleki yabancı dil dersleri farkı sektörlere nitelikli eleman yetiştiren önlisans programları için oldukça gerekli bir derstir. Mesleki yabancı dil dersleri, meslek yüksekokullarında zorunlu derslerinden sonra genellikle 3. ve 4 . yarıyılda yer alan derslerdir. Bu derslerin amacı, genel olarak öğrencilere kendi mesleklerinde ihtiyaç duyacakları yabancı dil becerilerini kazandırmaktır. Ancak, Türkiye'de, İngilizce öğretiminden birçok nedenden dolayı istenilen seviyede verim alınamadığı görülmektedir (Akın, 2010; İgrek, 2013). Mesleki İngilizce derslerinde de durum farklı değildir; çünkü öğrencilerin İngilizce ön öğrenmelerinin yetersizliği ve Ingilizce derslerine karşı olumsuz duygu ve düşüncelere sahip 
olmaları Mesleki İngilizce derslerinde başarılı olma olasııılarını düşürmektedir. Bu derslerde de öğrenciler İngilizce seviyelerine göre gruplandırılmadıkları için, farklı dil seviyesindeki öğrenciler aynı programı takip etmektedirler. Ayrıca, zorunlu yabancı dil derslerinde başarısız olan öğrencilerin de mesleki yabancı dil derslerini alabilmeleri bu derslerdeki başarının düşük olma sebepleri arasındadır.

Mesleki yabancı dil derslerinde, dilin yapısından çok kullanımına odaklanılması, iletişim odaklı ve gereksinimlere uygun ders tasarımları yapılması, öğrencilerin derste daha başarılı olmalarını (bilişsel) ve dersten zevk almalarını (duyuşsal) sağlamak ve derse katılımlarını arttırmak (devinişsel) açısından oldukça önemlidir. Bu amaçlara ulaşmak için, öğretimin farklılaştırılması ve öğrenci gereksinimlerine uygun hale getirilmesi gerekmektedir. Sternberg, Grigorenko ve Zhang (2008)'a göre, öğretmenler, çocuk, genç ya da yetişkin hangi seviyede eğitim verirlerse versinler, öğretimin daha etkili olması için öğrencilerin düşünme stillerine göre öğretimi farklılaştırmalıdırlar. Bu öneriden yola çıkılarak, öğrencilerin düşünme stillerinin belirlenmesinin ve bu stillere göre mesleki yabancı dil dersi öğretimini farklılaştırmanın onlara daha etkili öğrenme ortamlarının hazırlanmasına, İngilizce'yi daha kolay ve kalıcı olarak öğrenmelerine ve hem derse hem de genel olarak İngilizce'ye olan tutumlarına olumlu yönde katkı sağlayacağı düşünülmüştür. Alanyazın taraması sonucunda, farklılaştırılmış öğretim stratejilerinin önlisans düzeyinde herhangi bir derste deneysel olarak incelenmediği görülmüştür. Ayrıca, düşünme stilleri ve farklılaştırılmış öğretimin bir arada uygulandığı deneysel bir çalışmaya rastlanmamıştır. Bu çalışma, farklılaştırılmış öğretim stratejilerinin önlisans düzeyinde Mesleki Yabancı Dil dersinde uygulanması, farklılaştırma yapılırken öğrencilerin düşünme stillerinin dikkate alınması ve yürütülen deneysel çalışma ile ilgili öğrenci görüşlerini yansıtması sebebiyle önemlidir.

Bu çalışmada, önlisans düzeyinde Mesleki Yabancı Dil II dersi kapsamında "Rezervasyon Yapma" ve "Otele Giriş-Çıkış İşlemleri" üniteleri için öğrencilerin öğrenme profillerine önemli etkileri olan düşünme stillerine göre süreç farklılaştırılmış ve farklılaştııılmış öğretim stratejilerinden istasyon, karmaşık öğretim, yörünge çalışmaları, merkezler, giriş noktaları ve öğrenme sözleşmelerinin kullanıldığı öğretim süreci tasarlanmış ve uygulanmıştır. Bu çalışmanın amacı, uygulama sürecinde kullanılan farklılaştırılmış öğretim etkinlikleri ile ilgili öğrenci görüşlerini belirlemektir. Bu amaca ulaşmak için aşağıdaki sorulara cevap aranmıştır:

1. Öğrencilerin kullanılan etkinliklerin öğrenmelerini nasıl etkilediğine ilişkin görüşleri nelerdir?

2. Öğrencilerin derste kendilerini nasıl hissettiklerine ilişkin görüşleri nelerdir?

3. Öğrencilerin derse katılımlarına ve motivasyon düzeylerine ilişkin görüşleri nelerdir?

4. Öğrencilerin okutmanın yönlendirme ve yardımlarına ilişkin görüşleri nelerdir?

5. Öğrencilerin uygulama sürecinin işleyişine ilişkin görüşleri nelerdir?

\section{YÖNTEM}

\subsection{Araştırma Deseni}

$\mathrm{Bu}$ betimsel çalışmada nitel araştırma yöntemlerinden durum çalışması deseni kullanılmıştır. Durum çalışması, araştırılan olguyu kendi yaşam çerçevesi içinde inceleyen, olgu ve içinde bulunduğu ortam arasındaki sınırların kesin hatlarla belirgin olmadığı ve birden fazla kanıt veya veri kaynağının mevcut olduğu durumlarda kullanılan bir araştırma yöntemidir (Yıldırım ve Şimşek, 2011). Bu çalışmada, öğrencilerin düşünme stillerine göre farklılaştırılmış öğretim etkinlikleri hakkındaki görüşleri kendi sınırları içerisinde derinlemesine incelenmiştir.

\section{2 Çalışma Grubu}

Araştırmanın çalışma grubunu, 2014-2015 Bahar yarıyılında, bir Meslek Yüksekokulu'nun Turizm ve Otel İşletmeciliği Programı́nda öğrenim gören ikinci sınıf öğrencileri oluşturmaktadır. Araştırmaya, 12 kız 13 erkek toplam 25 öğrenci katılmıştır. Amaçlı örnekleme yöntemlerinden kolay ulaşılabilir durum örneklemesi yöntemi kullanılmıştır. 


\subsection{Uygulama Süreci}

Çalışmada, uygulama öncesinde öğrencilerin düşünme stilleri tespit edilmiştir. Düşünme stillerinin özellikleri, dersin içeriği, belirlenen üniteler ve hazırlanan materyaller göz önünde bulundurularak çalışmada düşünme stillerinin işlev düzey ve kapsam boyutlarının işe koşulmasına karar verilmiştir. Işlev boyutunda 14 öğrencinin yasayapıcı, 7 öğrencinin yürütmeci, 4 öğrencinin yargılayıcl; düzey boyutunda 13 öğrencinin bütünsel, 12 öğrencinin ayrıntısal; kapsam boyutunda 13 öğrencinin içedönük, 12 öğrencinin dışadönük düşünme stilline sahip olduğu tespit edilmiştir. Öğrencilerin düşünme stillerine göre etkinlikler farklılaştııılmıştır. Farklılaştırma, süreç boyutunda yapılmış ve süreç farklılaştırılırken dersin içeriği, belirlenen üniteler ve hazırlanan materyaller dikkate alınarak kullanılabilecek farklılaştırılmış öğretim stratejileri belirlenmiştir. Uygulama sürecinde, kullanılan düşünme stillerinin boyutları ve farklılaştırılmış öğretim stratejileriyle ilgili bir model oluşturulmuş ve Şekil 1'de verilmiştir. Haftada 6 saat olan Mesleki Yabancı Dil II dersinde, düşünme stillerine göre farklılaştırılmış etkinlikler hazırlanmış ve ders planları oluşturulmuştur. Hazırlanan ders planları ve etkinlikler hakkında, eğitim programları ve öğretim alanından 4 uzmanının görüşleri alınmış ve görüşleri doğrultusunda ders planlarına, etkinliklere ve çalışma yapraklarına son hali verilmiştir. 42 ders saati boyunca uygulama yapılmıştır.

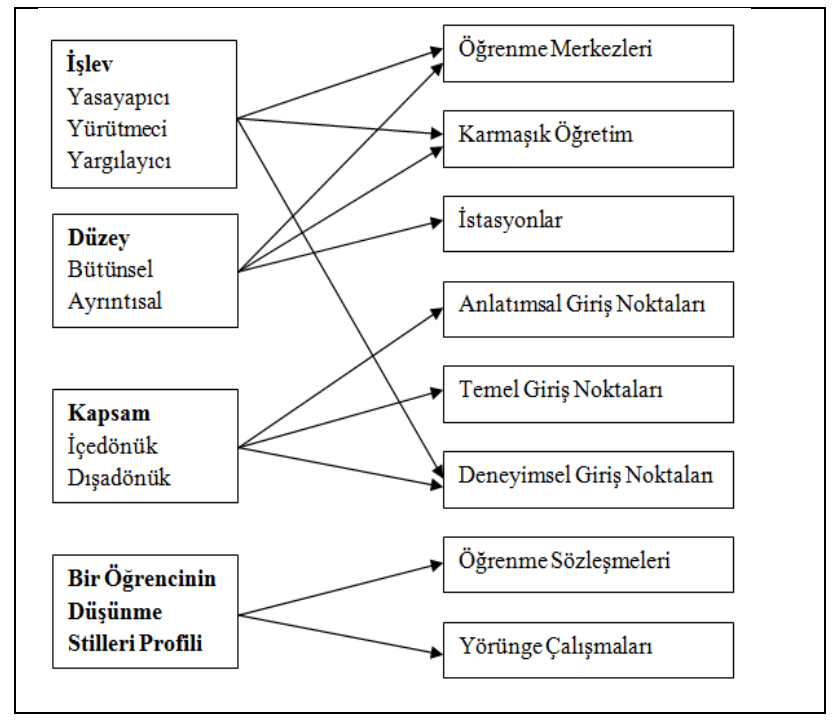

Şekil 1. Araştırmada işe koşulan model

Şekil 1'de görüldüğü üzere, öğrencilerin düşünme stillerinin işlev boyutunun dikkate alındığı derslerde öğrenme merkezleri, karmaşık öğretim ve deneyimsel giriş noktaları stratejileri işe koşulmuştur. Öğrencilerin düşünme stillerinin düzey boyutunun dikkate alındığı derslerde öğrenme merkezleri, karmaşık öğretim ve istasyon stratejileri işe koşulmuştur. Öğrencilerin düşünme stillerinin kapsam boyutunun dikkate alındığı derslerde anlatımsal, temel ve deneyimsel giriş noktaları işe koşulmuştur. Her bir öğrencinin düşünme stilleri profilinin dikkate alındığı ve öğrencilerin bireysel olarak yürüttükleri ders dışı çalışmalarda öğrenme sözleşmeleri ve yörünge çalışmaları stratejileri işe koşulmuştur. Derste uygulanan bazı etkinlikler aşağıda ayrıntılı olarak anlatılmışır.

Öğrenme Merkezleri: Öğretmen, öğrencileri düşünme stillerinin işlevlerine göre yasayapıcı, yürütmeci, yargılayıcı olarak gruplandırır. 2 yasayapıcı, 1 yürütmeci ve 1 yargılayıcı öğrenme merkezi oluşturur. Yasayapıcı öğrenme merkezinde, öğrencilere 20 farkı resim verilir. Öğrenciler resimleri inceler ve resimleri ifade eden İngilizce kelimeleri bulurlar. Burada doğru veya yanlış kelime yoktur. Resmi ifade edebilecek herhangi bir kelime bulmaları yeterlidir. Daha sonra, buldukları kelimelerle anlamlı cümleler kurarlar. Yürütmeci öğrenme merkezinde, öğrencilere 20 resim ve 20 kelime verilir. Öğrenciler verilen resimlerle İngilizce kelimeleri eşleştirirler. Verilen 
kelimeleri içeren bir bulmacayı çözerler. Son olarak, bu kelimeleri kullanarak anlamlı cümleler kurarlar. Yargılayıcı öğrenme merkezinde, öğrencilere 20 resim ve bu kelimelerden oluşan bir bulmaca verilir. Öğrenciler grup arkadaşlarıyla tartışarak resimde ifade edilmek istenen kelimelerin bulmacadaki harf sayısını dikkate alarak her bir resim için doğru kelimeyi bulmaya çalışırlar. Burada tek bir doğru kelime vardır. Resimlere göre bulmacayı çözdükten sonra, bu kelimeleri kullanarak anlamlı cümleler kurarlar (1 ders saati).

Karmaşık Öğretim: Öğretmen, öğrencilerin düşünme stillerinin düzeylerini dikkate alarak bütünsel ve ayrıntısal öğrenciler heterojen olacak şekilde gruplar oluşturur. Sonuçta 3 bütünsel-2 ayrıntısal ya da 3 ayrıntısal-2 bütünsel olacak şekilde beşer kişiden oluşan 5 grup oluşturur. Buradaki amaç; bütünsel öğrencilerin genele, ayrıntısal öğrencilerin de ayrıntılara odaklanarak birbirlerinin öğrenmelerine destek sağlamalarıdır. Çalışma yaprağının birinci bölümünde, öğrenciler rezervasyon yapma ile ilgili kelimeleri anlamlarına uygun olarak cümlelerdeki boşluklara yerleştirirler. İkinci bölümde, öğrenciler bir rezervasyon diyalogu okurlar. Üçüncü bölümde, bu diyalogla ilgili soruları cevaplarlar. Son bölümde, rezervasyon yaparken kullanılan sorular ve verilebilecek olası cevapları eşleştirirler (2 ders saati).

Deneyimsel Giriş Noktaları: Öğretmen, öğrencileri düşünme stillerinin kapsam boyutuna göre içedönük ve dışadönük olarak ayırır. Bu etkinlikte içedönük öğrenciler bireysel olarak, dışadönük öğrenciler ise, daha önceden belirlenen şekilde gruplar halinde çalışırlar. Otele giriş yapan bir misafir ile resepsiyonistin konuşmasını içeren bir video belirli bir yere kadar izletilerek öğrencilere bazı sorular sorulur ve öğrencilerin video hakkında konuşmaları sağlanır. Daha sonra videonun kalan kısmı izletilir. Çalışma yaprakları dağıtılır. Öğrenciler videoyu üç kez izler ve soruları cevaplarlar. Her dinleme sonunda biraz zaman verilerek grup halinde çalışan öğrencilerin cevapları tartışması ve bireysel olarak çalışan öğrencilerin cevaplar üzerinde düşünmesi sağlanır. Daha sonra tüm öğrencilerle cevaplar kontrol edilir. Tüm cevaplar verilmiş bir biçimde video son kez izlenir (2 ders saati).

Yörünge Çalışmaları: Öğrencilere "Rezervasyon Yapma" ve "Otele Giriş ve Çıkış İşlemleri" üniteleri boyunca yörünge çalışmaları aracılı̆̆ıla projeler yapacakları söylenir. Bu projeler, işlenen ünitelerin "yörüngesinde" yani etrafında döndüğü için bu adı almıştır. Yörünge çalışmaları hem ilgi çekici hem de öğrencilerin bağımsız çalışmasına olanak veren öğrenme stratejisidir. Öğrenciler, proje için "Rezervasyon Yapma" ve "Otele Giriş ve Çıkış İ̧̧lemleri" üniteleriyle ilgili konuları kendileri seçerler. Bu nedenle, şimdiye kadar işlenen konular, yapılan etkinlikler dikkate alınarak öğrencilerin bir konu belirlemeleri istenir. Tüm öğrencilere, projelerini iki ünitenin sonunda sunacakları belirtilir. Konuya, nasıl çalışacaklarına ve projeyi nasıl sunacaklarına karar veren öğrenciler, okutmanla birlikte bunları not ederler. Okutman, öğrencilere konu seçiminde ve proje sırasında rehberlik eder. Hiçbir konu bulamayan öğrencilere, yol göstermek amacıyla okutman aşağıdaki seçenekleri sunar. Öğrenciler hangi konuyu, nasıl çalışacaklarına ve nasıl sunacaklarına karar vermek için arkadaşlarıyla fikir alışverişinde bulunurlar (2 ders saati)

Olası Proje Konuları:

1. Bir otele giderek resepsiyonda yapılan konuşmaları gözlemlemek, not almak.

2. Bir otele giderek resepsiyonda yapılan konuşmaları videoya kaydetmek, daha sonra incelemek.

3. Internetten bir diyalog (rezervasyon/giriş-çıkış işlemleri) bularak bunu resimlerle anlatmak.

4. Rezervasyon/giriş-çıkış işlemleri ile ilgili bir diyalog yazmak ve bunu sınıfta arkadaşlarıyla canlandırmak.

5. Rezervasyon/giriş-çıkış işlemleri ile ilgili bir diyalog yazarak bu diyalogu arkadaşılla canlandırarak ses kaydı yapmak.

6. Rezervasyon/giriş-çıkış işlemleri ile ilgili bir diyalog yazarak bu diyalogu arkadaşıyla canlandırarak videoya çekmek.

7. Bir otel tanıtımı/reklamı hazırlamak. 
8. Bir TV kanalı spikeri bir otelde konaklama, oda özellikleri ve fiyatlar hakkında bilgi almak istiyor, otel müdürü ile röportaj yapmak vb.

Olası Sunum Yöntemleri: Video gösterimi, karikatür, resim, powerpoint sunusu, ses kaydı /dinleme, role-play (canlandırma), kavram haritaları vb.

\subsection{Veri Toplama Araçları}

Öğrencilerin düşünme stillerine göre farklılaştırılmış öğretim etkinlikleri hakkındaki görüşlerini belirlemek amacıyla yürütülen bu çalışmada 6 adet açık uçlu sorudan oluşan görüşme formu kullanılmıştır. Illgili alanyazın taramaları neticesinde elde edilen kuramsal ve deneysel çalışmalar incelenerek araştırmada kullanılabilecek sorular belirlenmiştir. Hazırlanan görüşme formuna ilişkin eğitim programları ve öğretim alanından iki uzmanın görüşlerine başvurulmuş ve görüşler doğrultusunda forma son hali verilmiştir. Uygulama sürecinin bitiminde öğrencilere görüşme formu verilmiş ve doldurmaları istenmiştir. Öğrenciler, formu doldurarak sonraki hafta içerisinde teslim etmişlerdir. Araştırmada kullanılan görüşme formunda aşağıdaki sorular yer almaktadır:

1. Mesleki Yabancı Dil dersinin "Rezervasyon Yapma" ve "Otele Giriş ve Çıkış İşlemleri" ünitelerinin öğretiminde sizin düşünme eğilimlerinize uygun olarak düzenlenen farklılaştırılmış öğretim etkinlikleri kullanılmıştır. Dersin bu şekilde yürütülmesi öğrenmeniz açısından şimdiye kadar gördüğünüz yabancı dil dersleri göz önüne alındığında sizi nasıl etkiledi?

2. Derste kendinizi nasıl hissettiniz?

3. Derse katıııınız hakkında ne düşünüyorsunuz?

4. Derse motive olma sıkıntısı yaşadınız mı? Neden?

5. Derste okutmanın yönlendirme ve yardımlarını yeterli buldunuz mu?

6. Uygulama sürecinde sorun yaşandığını düşünüyor musunuz? Sizce yaşanan sorunlar nelerdi?

\subsection{Veri Analizi}

Verilerin analizinde betimsel analiz yaklaşımı kullanılmıştır. Herhangi bir yazılımdan yararlanılmamış, geleneksel nitel veri analizi ile çözümleme yapılmıştır. Öğrencilerin görüşme formunu teslim etme sırasına göre, formlara numara verilerek, öğrencilerin kendi el yazılarıyla kaleme aldıkları cevaplar bilgisayar ortamına aktarılmıştır. Öğrencilerin sorulara verdikleri cevaplar genel olarak incelendikten sonra, belirli kategoriler oluşturulmuş ve benzer öğrenci görüşleri bu kategoriler altında toplanmıştır. Katılımcıların görüşlerinin daha doğru bir biçimde yansıtılabilmesi için doğrudan alıntılara yer verilmiştir. Doğrudan alıntılar yapıırken, her bir öğrenci için "Ö" harfi, formu teslim etme sırası için 1, 2, 3, 4 ... şeklinde sayısal kodlar ve cinsiyetlerini belirtmek için " $E$ " ve "K" harfleri kullanılmıştır. Örneğin birinci sırada formu teslim eden erkek öğrenci için "Ö, 1, E" kodu kullanılmıştır.

\section{BULGULAR}

Öğrencilerin düşünme stillerine göre farklılaştırılmış öğretim etkinliklerinin kullanılması, şimdiye kadar gördükleri yabancı dil dersleri göz önüne alındığında, öğrencilerin öğrenmelerini olumlu yönde etkilemiştir. Ayrıca, öğrenciler bu olumlu etkinin farklı sebeplerden kaynaklandığını ifade etmişlerdir. Öğrencilerin bu sebeplerle ilgili verdikleri cevaplar Tablo 2'de verilmiştir.

Tablo 2. Öğrencilerin kullanılan etkinliklerin öğrenmelerini nasıl etkilediğine ilişkin görüşleri

\begin{tabular}{lcc}
\hline ifadeler & $f$ & $\%$ \\
\hline Konuları öğrenmemi kolaylaştırdı. & 9 & 36 \\
Derse olan ilgim arttı. & 8 & 32 \\
Dersin uygulamalı işlenmesi faydalı oldu. & 8 & 32 \\
Değişik etkinlikler yaptık. & 6 & 24 \\
\hline
\end{tabular}




\begin{tabular}{|c|c|c|}
\hline Okutman öğrencilerin derse katılımını sürekli teşvik etti. & 5 & 20 \\
\hline Benzer diyalogların kullanılması öğrenmemi kolaylaştırdı. & 5 & 20 \\
\hline Kelime dağarcığımı geliştirdi. & 5 & 20 \\
\hline Derse katılımım arttı. & 5 & 20 \\
\hline Diyalogları canlandırmak faydalı oldu. & 5 & 20 \\
\hline Dinleme etkinlikleri faydalı oldu. & 4 & 16 \\
\hline Video izlemek faydalı oldu. & 4 & 16 \\
\hline Dersler sıkıcı geçmedi. & 3 & 12 \\
\hline Dersler öğrenci katılımıyla işlendi. & 3 & 12 \\
\hline Cümle kalıplarını öğrendim. & 3 & 12 \\
\hline Görsel materyallerin kullanımı faydalı oldu. & 2 & 8 \\
\hline Telaffuz konusunda sorunlarım azaldı. & 2 & 8 \\
\hline Devamsızlık nedeniyle pek öğrenemedim. & 2 & 8 \\
\hline Yapılan etkinlikler etkileyici idi. & 1 & 4 \\
\hline İngilizcenin eğlenceli yönlerini öğrendim. & 1 & 4 \\
\hline Dersi sevmemi sağladı. & 1 & 4 \\
\hline Sanki İngilizce öğrenmeye yeni başladım. & 1 & 4 \\
\hline İngilizce konuşabildiğimi hissettim. & 1 & 4 \\
\hline Sorularıma cevap aldım. & 1 & 4 \\
\hline Motivasyonum arttı. & 1 & 4 \\
\hline Öğrenilen konuları pekiştirmemde etkili oldu. & 1 & 4 \\
\hline İş hayatında faydalı olacak bilgiler öğrendim. & 1 & 4 \\
\hline Mesleki Yabancı Dil dersleri böyle işlenmeli. & 1 & 4 \\
\hline Uygulanan teknikler daha sık kullanılmalı. & 1 & 4 \\
\hline
\end{tabular}

Bu konu ile ilgili bazı öğrenci görüşleri şu şekildedir:

"Daha önceki derslerimizde, bu konuları hiç görmedim. ilk defa görmemize rağmen, hemen öğrendik. Karşılıkı konuşmalar yaptık. Diyaloglar dinledik, onları anlamaya çalıştık. Öğrenebilmemiz için hocamız elinden geleni yaptı. Bu bizim derse motivasyonumuzu arttırdı" (Ö, 6, K).

"Sanki yeni Ingilizce öğrenmeye başladım. Keşke daha önceki yıllarda da bu sistem olsaydı." (Ö, 9, E).

"Dinleme etkinlikleri ve konuşmalar konuları anlamama daha çok yardımcı oldu. Yabancı dil derslerine zevk alarak katılmıyordum. Ama bu dersteki etkinlikler beni etkiledi ve ingilizce dersine katılmama yardımcı oldu." (Ö, 11, K).

"Diğer yabancı dil derslerinin daha sıkıcı ve ezbere, yazmaya dayalı geçmesinden sonra, Mesleki Yabancı Dil dersinin bu dönem otele dair her şeyi uygulamalı olarak içermesi, görsellerin kullanılması, dinlemeye yönelik olması ve etkileyici ve faydalı etkinliklerin kullanılması çok hoşuma gitti." (Ö, 14, K).

"Dilim yatkınlaştı. Eğlenceli yönlerini öğrendim. Kelime dağarcığım gelişti. Zevkli metotlar uygulandı. Dersten kopulmadan ders işlendi. Herkes daima dersle ilgili idi." (Ö, 15, E).

"Etkinlikler sayesinde dersi sevmeye başladık. O yüzden öğrenmeye başladık ve kesinlikle daha kolay öğrendik." (Ö, 17, K).

"Videolar ve uygulamalı olarak birçok diyalog okunması daha iyi oldu. Dersler sıkıcı geçmedi ve ilgimizi arttırdı. Özellikle videolar izlediğimiz zaman, aklımızda kalmasını ve hafızamızda canlanmasını sağladı ve eğlenceli dakikaları arttırdı. Kesinlikle böyle devam edilmeli." (Ö, 18, K). 
“Çok güzel etkiledi. Çünkü daha önceki ingilizce derslerinde üstün körü eğitim almıştık. Soru sorma yok, cevap alma yok. Burada video ve karşılıklı diyaloglarla daha güzel oldu. Sormak istediğim soruları sorup cevaplarını aldım." (Ö, 22, E).

"Daha önceki ingilizce derslerinde pek bir şey anlamaz ve sıkılırdım. Çok iyi işledik. Hocamızın bize yardımları sayesinde daha kolay öğrendim. Diğer ingilizce derslerinde böyle değildi." (Ö, 23, K).

Öğrencilerin büyük çoğunluğu, derste kendilerini nasıl hissetiklerine ilişkin olumlu ifadeler kullanmışlardır. Öğrencilerin verdikleri cevaplar Tablo 3'te verilmiştir.

Tablo 3. Öğrencilerin derste kendilerini nasıl hissettiklerine ilişkin görüşleri

\begin{tabular}{lll}
\hline Ifadeler & $f$ & $\%$ \\
\hline Dersten zevk aldım. & 6 & 24 \\
İyi hissettim. & 4 & 16 \\
Özgüvenim arttı. & 3 & 12 \\
Korkmadan derse katıldım. & 3 & 12 \\
Mutlu hissettim. & 3 & 12 \\
Öğrendiğimi hissettim. & 3 & 12 \\
Motivasyonum arttı. & 2 & 8 \\
Derste sıkılmadım. & 2 & 8 \\
Derste sıkıldım. & 2 & 8 \\
Ingilizceyi öğrenmeye başlıyormuşum gibi hissettim. & 2 & 8 \\
Heyecanlandım. & 1 & 4 \\
Rahat hissettim. & 1 & 4 \\
Huzurlu hissettim. & 1 & 4 \\
Dikkatim daha az dağıldı. & 1 & 4 \\
Kötü hissettim. & 1 & 4 \\
\hline
\end{tabular}

Bu konu ile ilgili bazı öğrenci görüşleri şu şekildedir:

"Fransız hissettim ilk başlarda. Daha sonra öğrendikçe keyif aldım. Özgüvenim arttı." (Ö, 1, E).

"Bazen sıkıldım bazen zevk aldım." (Ö, 3, E).

"Ingilizceyi öğrenmeye başlıyormuşum gibi hissettim." (Ö, 5, K).

"Derse katıldı̆ı̆m zaman kendimi hemen öğrenmiş hissediyorum. Hocamızın yaptırdığı aktiviteler beni eğlendirdi ve daha çabuk kavradım." (Ö, 6, K).

"Hiçbir şey bilmediğimi anladım." (Ö, 9, E).

"Genelde kötü. Uyku problemim olduğu için derse aktif bir şekilde katılamıyorum." (Ö, 12, E).

"Çok mutlu ve rahat. Eğlendiğimi hissettim. Derse katılmak ve hep birlikte etkinlik yapma çabalarımız hoşuma gitti. Hata yapmaktan korkmadan rahatça düşüncelerimi söyleyebildim." (Ö, 18, K).

"Mutlu ve huzurlu, çünkü öğrendim." (Ö, 22, E).

Öğrencilerin derse katııım düzeyleri ile ilgili olarak, çoğu öğrenci derse yeterince katıldığını $(f=20)$; birkaç öğrenci ise yeterince katılmadığını $(f=5)$ belirtmiştir. Bu durumun sebebini ise, öğrenciler süreci göz önünde bulundurarak farklı şekilde ifade etmişlerdir. Bu konudaki bazı öğrenci görüşleri şu şekildedir:

"Çok katılmıyorum. Hocamız ilgilendikçe katılıyorum." (Ö, 3, E).

"Katılmak istediğim zamanlarda katıldım." (Ö, 5, K).

"Dersin işleniş biçimi daha çok hoşuma gittiği için, çoğu konularda derste aktif olmaya çalıştım." (Ö, 7, K). 
"Yeterince katıldım. Kaçırmamam gereken bir ders. Çünkü dili seviyorum. Ama kaplumbağadan daha yavaşım." (Ö, 9, E).

"Hocamızın teşvik ve desteğiyle derse katıldım. Her derse katıldım. Bu da benim dersi sevmeme ve anlamama yardımcı oldu." (Ö, 10, E).

"Büyük oranda katıldı̆̆ımı düşünüyorum. Özellikle eskiye oranla ilgimin ve alakamın arttığııı düşünüyorum. Bu çok hoşuma gidiyor." (Ö, 18, K).

"Derse katıldıkça daha çok bilgi öğreniyorum." (Ö, 19, E).

Ayrıca, öğrencilerin çok azı motive olma sıkıntısı yaşadıklarını $(f=4)$, bir kısmı bazen yaşadıklarını $(f=11)$ ve bir kısmı da hiç motive olma sıkıntısı yaşamadıklarını $(f=10)$ ifade etmişlerdir. Bu konu ile ilgili bazı öğrenci görüşleri şu şekildedir:

"ilk başlarda hep ingilizce konuşmaya çalışıyorduk, motive olamamıştım. Ama sonradan alıştım." (Ö, 3, E).

"Bazen yaşadım. Dersin son saatte olması beni yordu." (Ö, 5, K).

"Derslere ilk başladığımızda, bilgi azlığımdan dolayı pek motive olamadım. Sonradan yaptığımız çalışmalarla, daha kolay öğrenmeye başladığım için daha motive olmaya başladım." (Ö, 7, K).

"Hayır. Başta bu dersin ders saatlerinin fazla olması kötü gelirken, şimdi daha eğlenceli geçtiği ve gerçekten öğrenmeye başladığımı için az bile geldiğini düşündüm." (Ö, 14, K).

"Başlangıçta yaşamıştım fakat zamanla hiç kalmadı, bunda ders saatlerinin payı da olabilir." (Ö, 16, K).

"ilk başlarda evet ama şimdi iyi olduğumu düşünüyorum." (Ö, 20, K).

"Başlarda evet, ama daha sonra aktif oldum." (Ö, 24, E).

"Evet. Liseden gelen ingilizceye ilgisizlik beni üniversitede de etkiledi." (Ö, 12, E).

Öğrencilerin hepsi, derste okutmanın yönlendirme ve yardımlarını yeterli bulduklarını ifade ederek farklı açıklamalarda bulunmuşlardır. Öğrencilerin verdikleri cevaplar Tablo 4'te verilmiştir.

Tablo 4. Öğrencilerin derste okutmanın yönlendirme ve yardımlarına ilişkin görüşleri

\begin{tabular}{lll}
\hline ifadeler & $f$ & $\%$ \\
\hline Öğrencilerle bire bir ilgilendi. & 12 & 48 \\
Derse katılımı teşvik etti. & 8 & 32 \\
ìtiyaç duyulan her an yardımda bulundu. & 7 & 28 \\
Çeşitli ve değişik etkinlikler kullandı. & 4 & 16 \\
Telaffuz konusunda yardımcı oldu. & 4 & 16 \\
Sorulan sorulara tatmin edici cevaplar verdi. & 3 & 12 \\
Hataları düzeltti. & 3 & 12 \\
Açıklamaları örnekler kullanarak yaptı. & 3 & 12 \\
Öğretme çabası içerisindeydi. & 2 & 8 \\
Sürekli İngilizce konuştu. & 2 & 8 \\
Kelimelerin yazılışı konusunda yardımcı oldu. & 1 & 4 \\
Derslerde öğrencileri kontrol etti. & 1 & 4 \\
Daha kolay öğrenmemi sağladı. & 1 & 4 \\
Sabırlı idi. & 1 & 4 \\
Anlayışlı idi. & 1 & 4 \\
Pozitif davrandı. & 1 & 4 \\
İçten ve sıcak davrandı. & 1 & 4 \\
\hline
\end{tabular}




\begin{tabular}{lll}
\hline Rahat bir sınıf ortamı yarattı. & 1 & 4 \\
Canlı bir sınıf ortamı yarattı. & 1 & 4 \\
Zihnimi açtı. & 1 & 4 \\
\hline
\end{tabular}

Bu konu ile ilgili bazı öğrenci görüşleri şu şekildedir:

"Evet. Sürekli başımızda bekleyip sıkılmadan sorularımıza cevap verdi. Yanlışlarımızı düzeltti. Yeterince bilgi sahibi. Derste bizleri kontrol etmesi sayesinde boşa zaman harcamadık." (Ö, 4, E).

"Evet, yeterli buldum. Hocamızın bizimle ayrı ayrı ilgilenmesi, birçok etkinlikle dersi pekiştirmesinin bana çok yarar sağladığını düşünüyorum. İzlediğimiz videolar, yaptığımız ders içi etkinlikler ve hocamızın bizimle tek tek ilgilenmesi çok hoşuma gitti." (Ö, 7, K).

"Evet, hocamız bizlere yardımcı oluyor, birebir ilgileniyor, yapamadıklarımızı tekrarlıyor. Çok yardımcı olduğunu düşünüyorum. Birebir ilgilendiği için. Hatalarımızı düzelttiği için. Anlayışlı olduğu için. Öğrencilere içten ve sıcak davrandığı için." (Ö, 13, K).

"Kesinlikle yeterli. Kırmadan, incitmeden ve aşağılayıcı tavırlar kullanılmadığı için rahat bir ders işleniyordu. Tamamen pozitif. Iticilik yerine çekicilik. Boğulma, sıkılma yerine tamamen canlı ve heyecanlı dinç bir ders." (Ö, 15, E).

"Evet. Hocamı yeterince ilgileniyor ve herkesin derse katılması ve herkesin anlaması için uğraştığını düşünüyorum. Anlamadığım yerleri benden önce hocamın fark ettiği zamanlar oluyor ve beni yönlendiriyor ve bu çok hoşuma gidiyor. Anlaşılmadığı zamanlar herkesin ilgisini derse çekmek için bir açıklama yapıyor ve herkesin anlamadığı noktayı tek tek dinlemesi, ilgilenmesi ve benim için en önemlisi anlamadığım an onun benden önce farkında olup ilgilenip tekrar o konuya dönmesi çok önemli." (Ö, 18, K).

"Fazlasıyla yeterli buldum. Bizim daha kolay öğrenmemiz için yeni etkinlikler yapıyor derste. Bunun faydalı olduğuna inanıyorum." (Ö, 19, E).

"Evet, yeterli buldum. Motivasyonumu arttırmama yardımcı oldu ve zorlandığım konularda benimle birebir ilgilendi. Öğrencileriyle tek tek ilgilenmesi ve yaptığımı etkinlikler açısından oldukça yeterli buldum." (Ö, 21, K).

Uygulama sürecinin işleyişine ilişkin öğrenci görüşleri incelendiğinde, öğrencilerin çoğu $(f=15)$ sorun yaşanmadığını, bazı öğrenciler $(\mathrm{f}=10)$ ise sorun yaşandığını düşünmektedirler. Ancak, sorun yaşandığını düşünen öğrencilerin cevapları incelendiğinde, öğrencilerin uygulamadan kaynaklı sorunlardan ziyade genel olarak kendi kişisel önyargılarından, ön öğrenme eksikliklerinden ve haftalık programdaki ders saatlerinden (Mesleki Yabancı Dil Dersi iki gün öğrencilerin son iki ders saatinde idi) bahsettikleri anlaşılmaktadır. Konu ile ilgili bazı öğrenci görüşleri şu şekildedir:

"Yaşanan tek sorun alt yapımın olmaması ve yavaş yavaş kendimi geliştiriyorum. Hiç değilse, çalıştığım yerde bu derste öğrendiklerimle işimi halledebilirim." (Ö, 1, E).

"Bazen dersi çok yoğun işledik. Bu konuda (çok eksiğim olduğu için) sorun yaşadım." (Ö, 5, K).

"En azından bu dönem yaşadığımı düşünmüyorum. Derse daha çok katıldığım için, daha çabuk öğreniyorum." (Ö, 6, K).

"Uygulama sürecinde yaşadığım sorunların benim bilgi eksikliğimle alakalı olduğunu düşünüyorum. Derslerin genellikle son saatlere denk gelmesi yorucu oluyor." (Ö, 7, K).

"Hayır. Mümkün olduğunca değişik örnekler ve etkinliklerle konuyu işledik." (Ö, 8, E).

"Uygulama sürecinde hiçbir zaman sorun yaşamadım. Okutman sürekli ilgiliydi ve dinliyordu." (Ö, 16, K).

"Ben sorun yaşadığımı düşünmüyorum. Çünkü olumlu olarak başladım ve o şekilde devam ettim. Başka yaşanan sorunlar olduğunu da düşünmüyorum. Gördüğüm kadarılla herkesin ilgisi ve çabası belli bir düzeyde." $(0 \ddot{0}, 18, K)$. 


\section{SONUÇ, TARTIŞMA VE ÖNERILER}

Bu araştırmada, düşünme stillerine göre farklılaştırılmış öğretim etkinlikleri ile ilgili olarak öğrenci görüşlerinin olumlu olduğu sonucuna varılmıştır. Öğrenciler genel olarak, uygulamanın yapıldığı her iki ünitede geçen konuları öğrendiklerini düşünmektedirler. Alan yazında, öğrencilerin farklılaştırımış öğretimin öğrenmelerine faydalı olduğu ve öğrencilerin öğrenmekten keyif aldıkları, özellikle hazırlanan çalışma yapraklarının ve küçük grup öğretiminin kendileri için faydalı olduğu sonucuna ulaşan çalışmalar mevcuttur (Dosh, 2011; Stager, 2007). Ayrıca, düşünme stillerinin öğrencilerin öğrenmelerini ve akademik başarılarını olumlu etkilediği farklı çalışmalarda ortya konumuştur (Cano-Garcia ve Hughes, 2000; Grigorenko ve Sternberg, 1997; Sternberg ve Zhang, 2001; Zhang, 2001; Zhang, 2002; Zhang, 2004).

Bu çalışmada, düşünme stillerine göre farklılaştırılmış öğretim etkinliklerinin öğrencilerin öğrenmeleri açısından şimdiye kadar gördükleri yabancı dil dersleri göz önüne alındığında onları olumlu etkilediği ortaya çıkmıştır. Değişik çalışmalarda farklılaştırılmış öğretimin öğrencilerin öğrenmelerini olumlu etkilediği, derse olan ilgilerini arttırdığı ve arkadaşlık ilişsilerinin gelişimine yardımcı olduğu (Avcı ve diğ., 2009); öğrenciler ve öğretmenler açısından ders işlemenin eğlenceli ve kolay olduğu (Sondergeld ve Schultz, 2008); farklılaştırılmış öğretim uygulamaları ile öğrencilerin geniş zamanda, farklı görevler yaparak, arkadaşlarıyla tartışarak ve işbirliği içerisinde öğrenmeyi zevkli ve eğlenceli buldukları (Avcı ve Yüksel, 2011; Yüksel ve Avcı, 2011) sonuçlarına ulaşılmıştır. Bu araştırma sonucunda, yapılan etkinliklerin öğrencilerin konuları öğrenmelerinde etkili olduğu, kelime dağarcıklarını geliş̧tirdiği, telaffuz konusunda faydalı olduğu ve öğrenilen konuları pekiştirmede etkili olduğu anlaşılmıştır. Benzer şekilde, Lavender (2009)'ın çalışmasında, öğrencilerin sözcük dağarcıklarında anlamlı bir artış olduğu ve okuduğunu anlama becerilerinin geliş̧iği ortaya çıkmıştır. Ayrıca, öğrenciler, mesleki yabancı dil derslerinin bu şekilde işlenmesinden memnun kaldıkları için uygulanan tekniklerin daha sık işe koşulmasını önermişlerdir. Yüksel ve Avcı (2011), farklılaştırılmış öğretim ile ilgili öğrencilerle yaptıkları görüşmelerde, öğrencilerin diğer derslerde de bu uygulamaların yapılmasının iyi olacağını düşündükleri bulgusuna ulaşmışlardır. Araştırma bulguları, öğrencilerin düşünme stillerinin dil öğrenme stratejilerini etkilediği sonucuna varmış çalışmalar tarafından da desteklenmektedir (Ahmadi, Gorjian ve Pazhakh, 2014; Anjomshoaa, Golestan ve Anjomshoaa, 2012).

Bu araştırmada, düşünme stillerine göre farklılaştııılmış öğretim etkinliklerini kullanmanın dersi eğlenceli hale getirerek, derse ilgiyi ve katılımı arttırarak dersi sevdirdiği, dolayısıyla derse yönelik motivasyonu arttırdığı ve öğrencilerin daha kolay öğrendikleri ortaya çıkmıştır. Bu bulgu, farkılış̧tırılmış öğretim stratejilerinin değişik ders ve alanlarda uygulandığı ve öğrencilerin ilgi ve motivasyonlarını arttırarak daha kolay öğrenmelerini sağladığının ortaya konduğu birçok çalışma bulgusu ile paralellik göstermektedir (Avcl, 2015; Konstantinou-Katzi ve diğ., 2013; Oden, 2012; Sondergeld ve Schultz, 2008; Yüksel ve Avcl, 2011). Fan ve Zhang (2009) da öğrencilerin düşünme stillerinin öğrenmeye güdülenmelerine etkisi olduğu sonucuna ulaşmışlardır.

Araştırmada, öğrencilerin dersten zevk aldıkları, kendilerini iyi, rahat ve huzurlu hissettikleri, özgüven ve motivasyonlarının arttığı, korkmadan derse katıldıkları, mutlu oldukları, öğrendiklerini hissettikleri, derste sıkılmadıkları, İngilizceyi öğrenmeye başlıyormuş gibi hissettikleri, heyecanlandıkları, dikkatlerinin daha az dağıldığı, derse kendilerini vermeye çalıştıkları sonucuna varılmıştır. Öğrencilerin genellikle olumlu duygular içerisinde olması, Boerger (2005)'in gözlemlediği gibi, öğrencilerin konu ve etkinlikle daha kişisel bağlantılar kurmalarından, öğrencilerin kendi öğrenmelerini tespit edebilmelerinden ve hangi konuda daha fazla öğrenmeye ihtiyaçları olduğunu belirleyebilmelerinden kaynaklanmış olabilir. Bu bulgularla uyumlu olarak, alanyazında farklılaştırımış öğretim uygulamalarının öğrencilerin öğrenmekten keyif almasını sağladı̆̆ı (Stager, 2007), derse yönelik ilgi ve motivasyonlarını arttırdığı (Avcı ve diğ., 2009; Beler, 2010; Suarez, 2007), uygulamanın dersleri eğlenceli hale getirdiği ve öğrencilerin daha kolay öğrenmelerini sağladığı (Avcı ve Yüksel, 2011; Sondergeld ve Schultz, 2008; Yüksel ve Avcı, 2011), öğrencilerin gelişimini doğrudan etkilediği (Johnson, 2010), kendi öğrenmelerine ilişkin bir farkındalık geliştirerek 
öğrenme stillerini keşfetmelerini sağladığı (Karadağ ve Yaşar, 2010); okulda olmaktan zevk almayan öğrencilerin bile çok mutlu olmalarını sağladığı (Yüksel ve Avcı, 2011) gibi bulgular mevcuttur.

Bu araştırmada, öğrencilerin büyük bir kısmı derse yeterince katıldıklarını ifade etmiş ve çok az bir kısmı motive olma sıkıntısı yaşadığını belirtmiştir. Çalışma bulguları, farklılaştırılmış öğretim uygulamalarının öğrencilerin motivasyonunu arttırdığı (Avcı ve diğ., 2009; Batdı ve Semerci, 2012; Beler, 2010; Cheng, 2006; Suarez, 2007), dersi sevmelerini sağlayarak derslere daha istekli katılmalarında etkili olduğu (Avcı, 2015; Oden, 2012), derse ilgilerini ve katılımlarını arttırdığı (Konstantinou-Katzi ve diğ., 2013) ve öğrencilerin düşünme stilleri ile derslere yönelik tutumları arasında anlamlı ilişkiler olduğu (Çatalbaş, 2006) sonuçlarına ulaşmış alanyazında birçok çalışma tarafından desteklenmektedir.

Öğrencilerin hepsi, farklı açılardan değerlendirerek düşünme stillerine göre farklılaştırılmış öğretim etkinliklerinin kullanıldığı öğretim süreci boyunca okutmanın yönlendirme ve yardımlarını yeterli bulmuşlardır. Bu bulgu, Yüksel ve Avcı (2011)'nın farklılaştırılmış öğretim etkinliklerini uygulayan bir öğretmenin sürekli gruplar içinde gezerek rehberlik yapması gerektiği bulgusu ile ve Burkett (2013)'in farklılaştırılmış öğretimin etkili bir sınıf ortamı oluşturmak için gerekli olduğu ve bu sınıf ortamının öğrenmeye yardımcı olduğu bulguları ile örtüşmektedir. Bu nedenle, çalışmada okutmanın iyi bir planlama sayesinde, öğrenci beklentilerini ve intiyaçlarını karşılamada başarılı olduğu söylenebilir.

Araştırmada, öğrencilerin büyük bir kısmı uygulama sürecinde sorun yaşanmadığını; bir kısmı da yaşandığını düşünmektedir. Bu bulgu, farklılaştırılmış öğretim stratejilerinin değişik ders ve alanlarda uygulandığı birçok çalışma bulgusu ile paralellik göstermektedir. Mergen (2011)'in çalışmasında, öğrencilerin olumlu görüşlerin ortalaması \%75.52, olumsuz görüşlerin ortalaması ise \%28.18 olarak belirlenmiştir. Benzer şekilde, Yüksel ve Avcı (2011)'in çalışmasında, öğrencilerin kendi öğrenmelerinden sorumlu oldukları, bu güce sahip oldukları, arkadaşlarından yardım almada ve arkadaşlarına yardım etmede istekli oldukları ve öğretmenler çok iyi planlama yaptığı takdirde, öğrencilerin öğrenme sürecinden zevk aldıkları ortaya çıkmıştır. Dolayısıyla, bu çalışmada iyi bir planlama ve yeterince yönlendirme yapılması sayesinde uygulama sürecinde sorun yaşanmadığı söylenebilir.

Düşünme stilleri, işlev, biçim, düzey, kapsam ve eğilim olarak 5 boyutta değerlendirilir ve her bir boyut kendi içinde farklı alt boyutlardan oluşmaktadır. Bu çalışma, öğrencilerin düşünme stillerinin işlev, düzey ve kapsam boyutları ve bu boyutların yasayapıcı, yürütmeci, yargılayıcı, bütünsel, ayrıntısal, içedönük ve dışadönük alt boyutları ile sınılıdır. Farklılaştırılmış öğretimde, öğrencilerin hazırbulunuşluk, ilgi ve öğrenme profillerine göre içerik, süreç veya ürünü farklılaştırılabilir. Çalışmada, farklılaştırma öğrencilerin öğrenme profillerine etkisi olan düşünme stillerine göre süreç boyutunda yapılmıştır. Ayrıca çalışma, farklılaştırılmış öğretim stratejilerinden istasyon, karmaşık öğretim, yörünge çalışmaları, merkezler, giriş noktaları ve öğrenme sözleşmeleri ile sınırlıdır.

Araştırma bulguları ve alanyazın dikkate alınarak şu önerilerde bulunulabilir: Yabancı dil derslerinde, öğrencilerin düşünme stillerine göre farklılaştırılmış öğretim etkinliklerinin kullanılması, daha fazla uygulama yapılmasını, kelime dağarcığını geliştiren ve cümle kalıplarını yansıtan etkinliklerin çeşitlendirilmesini ve görsel ve işitsel materyallerin kullanılmasını destekleyeceği için, öğrencilerin öğrenmelerini olumlu etkileyecektir. Bu uygulamalar, öğrencilerin eğlenerek öğrenmelerini, derse olan ilgi ve motivasyonlarını arttırarak korkmadan, severek ve isteyerek derse katılmalarını sağlamaya yardımcı olacaktır. Öğrencilerin derse aktif katıımını, öğrenci-öğrenci ve öğrenci-öğretmen etkileşimini arttırmak amacıyla farklılaştırılmış öğretim stratejileri kullanılabilir ve kullanılan materyallerin gerçeğe uygun olması ön planda tutulabilir. Yabancı dil öğretiminde, tüm dil becerilerine önem verilmelidir. Ancak öğretmenler öğrencilerin özellikle konuşmaya yönelik eksiklik, önyargı ve olumsuz düşüncelerini, öğrencilerle bire bir ilgilenerek, sabırlı ve anlayışlı olarak, içten, sıcak ve olumlu davranarak, rahat ve canlı bir sınıf 
ortamı oluşturarak giderilebilir ve öğrencilerin konuşmaya yönelik özgüven kazanmalarını sağlayabilirler.

Ileride yapılacak çalışmalarda, bu çalışmada yer verilmeyen düşünme stillerinin biçim ve eğilim boyutları dikkate alınarak kullanılan farklılaştırımış öğretim etkinliklerine ilişkin veya bu çalışmada kullanılmayan farkıılaştııımış öğretim stratejilerinin yabancı dil öğretiminde kullanımına ilişkin öğrenci görüşleri incelenebilir. Yabancı dil öğretiminde içerik ve ürün farklılaştırılarak yapılacak çalışmalara ilişkin öğrenci görüşleri araştırılabilir. Farklı eğitim kademelerinde ve farklı derslerde düşünme stillerine göre farklılaştırılmış öğretim etkinliklerine ilişkin öğrenci görüşleri ele alınabilir.

\section{Kaynakça}

Ahmadi, S., Gorjian, B. ve Pazhakh, A. R. (2014). The Effect of Thinking Styles of EFL Learners' Language Learning Strategies in Reading Comprehension. International Journal of Language Learning and Applied Linguistics World, 6 (4), 74-88.

Akın, G. (2010). Andragojik ilkelere Göre Geliştirilmiş Problem Temelli Mesleki ingilizce Eğitimi Programının Etkililiği. Yayınlanmamış doktora tezi. Ankara Üniversitesi.

Altundal, H. (2013). Öğretmen Adaylarının Düşünme Stilleri ile Matematik Öğretim Kaygısı Arasındaki iliş̧kinin incelenmesi. Yayınlanmamış yüksek lisans tezi. Necmettin Erbakan Üniversitesi.

Anjomshoaa, L., Golestan, S., ve Anjomshoaa, A. (2012). The Influences of Metacognitive Awareness on Reading Comprehension in Iranian English Undergraduate Students in Kerman, Iran. International Journal of Applied Linguistics \&English Literature, 1 (6), 193-198.

Avcı, H. (2015). Ingilizce Öğretiminde istasyon Tekniği Kullanımının Akademik Başarıya, Tutumlara ve Kalıcılığa Etkisi. Yayınlanmamış yüksek lisans tezi. Fırat Üniversitesi.

Avcı, S. ve Yüksel, A. (2011). Okuma Çemberi Yöntemine Göre Kitap Okumanın Öğrencilere Bilişsel ve Duyuşsal Katkıları. Kuram ve Uygulamada Eğitim Bilimleri, 11 (3), 1285-1300.

Avcı, S., Yüksel, A., Soyer, M. ve Balıkçıoğlu S. (2009). Şiir Bilgisi Konusu İçin Tasarlanmış Farklılaştırılmış Sınıf Ortamının Öğrenciler Üzerinde Yarattığı Bilişsel ve Duyuşsal Değişimler. Kuram ve Uygulamada Eğitim Bilimleri, 9 (3), 1069-1084.

Batdı, V. ve Semerci, Ç. (2012). Derslerde İstasyon Tekniği Uygulamasının Yansıtıcı Sorgulaması. Bartın Üniversitesi Eğitim Fakültesi Dergisi, 1 (1), 190-203.

Beceren, B. Ö. ve Özdemir, A. A. (2010). The Comparison of Prospective Preschool Teachers' Thinking Styles and Intelligence Types. Procedia Social And Behavioral Sciences, 2, 2131-2136.

Beler, Y. (2010). Farklılaştııılmış Öğretim Ortamının Sınıf Yönetimine ve Öğrencilerin Akademik Başarısına Etkisi. Yayınlanmamış yüksek lisans tezi. Maltepe Üniversitesi.

Boerger, M. V. (2005). Differentiated Instruction in the Middle School Math Classroom: A Case Study. Unpublished master thesis, Pacific Lutheran University.

Bradfield, A. (2012). The Effects of Differentiated Instruction on Strugling Readers in First Grade. Unpublished doctoral dissertation. Walden Unversity.

Burkett, J. A. (2013). Teacher Perception on Differentiated Instruction and its Influence on Instructional Practice. Unpublished doctoral dissertation. Oklahoma State University.

Canbolat, N. (2011). Matematik Öğretmen Adaylarının Teknolojik Pedagojik Alan Bilgileri ile Düşünme Stilleri Arasındaki Ilişkinin Belirlenmesi. Yayınlanmamış yüksek lisans tezi. Selçuk Üniversitesi.

Cano-Garcia, F. ve Hughes, E. H. (2000). Learning and Thinking Styles: An Analysis of their Interrelationship and Influence on Academic Achievement. Educational Psychology, 20 (4), 413430. 
Cheng, A. (2006). Effects of Differentiated Curriculum and Instruction on Taiwanese EFL Students' Motivation, Anxiety and Interest. Unpublished doctoral dissertation. University of Southern California.

Clarke, T. A., Lesh, J. J., Trocchio, J. S. ve Wolman, J. (2010). Thinking Styles: Teaching And Learning Styles in Graduate Education Students. Educational Psychology, 30 (3), 837-848.

Cummings, P. L. (2011). A Comparative Analysis of the Impact of Differentiated Instructional Strategies and Traditional Basal Instruction on the Reading Achievement of Selected Fourth Grade Students. Unpublished doctoral dissertation. Capella University.

Çalıkoğlu, B. S. (2014). Üstün Zekalıve Yetenekli Öğrencilerde Derinlik ve Karmaşıklığa Göre Farklılaştırılmış Fen Öğretiminin Başarı, Bilimsel Süreç Becerileri ve Tutuma Etkisi. Yayınlanmamış doktora tezi. İstanbul Üniversitesi.

Çatalbaş, E. (2006). Lise Öğrencilerinin Düşünme Stillerinin Akademik Başarı ve Ders Tutumları Arasındaki ilişki. Yayınlanmamış yüksek lisans tezi. Selçuk Üniversitesi.

Çitil, N. (2011). Fen Bilgisi Öğretmen Adaylarının Düşünme Stillerinin Bazı Değişkenler Açısından Karşılaştırılması. Yayınlanmamış yüksek lisans tezi. Fırat Üniversitesi.

Demir, Ö. ve Osmanoğlu, D. E. (2013). Lise Öğrencilerinin Düşünme Stillerinin Çeşitli Değişkenler Açısından Incelenmesi. Eğitim Bilimleri Araştırmaları Dergisi, 3 (1), 165-184.

Demir, S. (2013). Farklılaştırılmış Öğretim Yöntemlerinin Öğrencilerin Akademik Başarı, Öğrenme Yaklaşımları ve Kalıcılık Puanları Üzerindeki Etkisi. Yayınlanmamış doktora tezi. Yıldız Teknik Üniversitesi.

Dosh, M. V. (2011). "The Course Fit Us": Differentiated Instruction in the College Classroom, Dissertation, University of North Dakota, Graduate Faculty of University of North Dakota, Grand Forks.

Duman, B. ve Çelik, Ö. (2011). İlköğretim Öğretmenlerinin Düşünme Stilleri ile Kullandıkları Öğretim Yöntemleri Arasındaki İlişki. Illköğretim Online, 10 (2), 785-797.

Düzgün, Z. (2011). Fen ve Teknoloji Öğretmenlerinin Düşünme Stilleri ile Problem Çözme Becerileri Arasındaki ilişski. Yayınlanmamış yüksek lisans tezi. Marmara Üniversitesi.

Emir, S. (2011). Düşünme Stillerinin Farklı Değişkenler Açısından İncelenmesi. Hasan Ali Yücel Eğitim Fakültesi Dergisi, 15, 77-93.

Esmer, E. (2013). Öğretmen Adaylarının Zihinsel Stil Tercihlerinin (Düşünme Stillerinin) Incelenmesi. Yayınlanmamış doktora tezi. Yıldız Teknik Üniversitesi.

Fan, W. (2012). An Experimental Comparison of the Flexibility in the Use of Thinking Styles in Traditional and Hypermedia Learning Environments. Thinking Styles and Creativity, 7, 224-233.

Fan, W. ve Zhang, L. F. (2009). Are Achievement Motivation and Thinking Styles Related? A Visit Among Chinese University Students. Learning and Individual Differences, 19, 299-303.

Fan, J. ve Zhang, L. F. (2014). The Role Of Learning Environments in Thinking Styles. Educational Psychology: An International Journal Of Experimental Educational Psychology, 34 (2), 252-268.

Fan, W., Zhang, L. F. ve Watkins D. (2010). Incremental Validity of Thinking Styles in Predicting Academic Achievements: An Experimental Study in Hypermedia Learning Environments. Educational Psychology: An International Journal Of Experimental Educational Psychology, 30 (5), 605-623.

Fer, S. (2005). Düşünme Stilleri Envanterinin Geçerlik ve Güvenirlik Çalışması. Kuram ve Uygulamada Eğitim Bilimleri, 5 (2), 433-461.

Grigorenko, E. L., ve Sternberg, R. J. (1997). Styles of Thinking, Abilities, and Academic Performance. Exceptional Children, 63 (3), 295-312. 
Güçlüer, E. ve Kesercioğlu, T. (27-30 Haziran 2012). Fen ve Teknoloji Eğitiminde Farklılaştırılmış Öğretim ile Desteklenmiş Fen Öğretiminin Öğrenci Başarısına Etkisi Üzerine Bir Araştırma. 10. Ulusal Fen Bilimleri ve Matematik Eğitimi Kongresi. Niğde Üniversitesi, Niğde.

Güneş, E. ve Yalın, H. í. (2017). Çevrimiçi Öğrenme Ortamlarında Öğrencilerin Düşünme Stillerine Göre Düzenlenmiş Farklı Etkileşim Tasarımlarının Akademik Başarı ve Güdülenmeye Etkisi. Mustafa Kemal Üniversitesi Sosyal Bilimler Enstitüsü Dergisi, 14 (39), 275-299.

İgrek, E. (2013). Içerik Tabanlı Yabancı Dil Öğretim Yaklaşımının Mesleki Yabancı Dil (Ingilizce) Derslerinde Öğrencilerin Akademik Başarılarına Etkisi. Yayınlanmamış yüksek lisans tezi. Gazi Üniversitesi.

James, S. D. (2013). Does Differentiated Instruction Raise Student Performance in Mathematics: An Action Research Study. Unpublished doctoral dissertation. Capella University.

Johnson, E. (2010). Improving Students' Academic Achievement through Differentiated Instruction, Dissertation, Walden University Educational Leadership, Minneapolis.

Karabulut, E. (2014). Psikolojik Danışman Adaylarının Duygusal Zeka Düzeyleri ile Düşünme Stilleri Arasındaki illişki. Yayınlanmamış yüksek lisans tezi. Dokuz Eylül Üniversitesi.

Karadağ, R. ve Yaşar ş. (2010). Effects of Differentiated Instruction on Students' Attitudes towards Turkish Courses. Procedia Social and Behavioral Sciences, 9, 1394-1399.

Khin, P. H. ve Win, S. (2012). The Effect of Thinking Styles on Metacognitive Awareness of University Students. Universities Research Journal, 5 (7), 269-287.

Konstantinou-Katzi, P., Tsolaki, E., Meletiou-Mavrotheris, M. ve Koutselini, M. (2013). Differentiation of Teaching and Learning Mathematics: An Action Research Study in Tertiary Education. International Journal of Mathematical Education in Science and Technology, 44 (3), 332-349.

Lau, H. (2014). Thinking Styles, Motivational Orientations, and Academic Achievement in Learning Physics among Hong Kong Secondary School Students. Unpublished doctoral dissertation. The University of Hong Kong.

Lavender, D.R. (2009). The Effect of an in-Class Behavioral Intervention plus Differentiated Instruction Program on the Achievement and Behavior Outcomes of Verbally Disruptive 8th Grade Students with and without Co-Occurring Reading Delimitation. Unpublished doctoral dissertation. University of Nebraska.

Maxey, K. S. (2013). Differentiated Instruction: Effects on Primary Students' Mathematics Achievement. Unpublished doctoral dissertation. Northcentral University.

Mergen, H. H. (2011). Illköğretim 5. Sınıf Sosyal Bilgiler Dersinde Öğrenme Istasyonları Uygulamasının Akademik Başarıya ve Kalııılığa Etkisi. Yayınlanmamış yüksek lisans tezi. Afyon Kocatepe Üniversitesi.

Negari, G. M. ve Solaymani, M. (2013). The Relationship among Autonomy, Thinking Styles, and Language Learning Strategy Use in Iranian EFL Learners. International Journal of Linguistics, 5 (1), 332-347.

Nikoupoor, J., Alam, M. ve Tajbakhsh, M. (2012). Thinking Style and Achievement Motivation: A Survey Study among Iranian EFL Learners. International Journal of English and Literature, 2 (3), 89104.

Oden, C. G. (2012). Effects of Differentiated Instruction on Achievement of High School Business Education Students. Unpublished doctoral dissertation. North Central University.

Önkuzu, E. (2013). Hazırık Sınıfı Öğrencilerinin Öğrenme ve Düşünme Stilleri ile Yabancı Dilde Kelimenin Anlamını Tahmin Etme Başarıları Arasındaki ilişski. Yayınlanmamış yüksek lisans tezi. Gaziosmanpaşa Üniversitesi.

Özbaş, N. (2013). Sınıf Öğretmenlerinin Düşünme Stillerinin Kullandıkları Yöntemler ve Epistemolojik Inançları Açısından Incelenmesi. Yayınlanmamış yüksek lisans tezi. Amasya Üniversitesi. 
Öztabak, M. Ü. (2013). Farklı Okul Türlerinde Öğrenim Gören Lise Öğrencilerinin Sınıf Seviyelerine Göre Düşünme Stilleri ile Karar Verme Stilleri Arasındaki ilişsinin Incelenmesi. Yayınlanmamış doktora tezi. İstanbul Üniversitesi.

Özyaprak, M. (2012). Üstün Zekâlı ve Yetenekli Öğrencilere Yönelik Farklılaştırılmış Matematik Öğretiminin Erişi, Tutum ve Yaratıcılığa Etkisi. Yayınlanmamış doktora tezi. İstanbul Üniversitesi.

Richmond, A. S. ve Conrad, L. (2012). Do Thinking Styles Predict Academic Performance of Online Learning? International Journal of Technology in Teaching and Learning, 8 (2), 108-117.

Samms, P. (2009). When Teachers Differentiate Reading Instruction for Fifth Grade Students: Impacts on Academic Achievement, Social and Personal Development, Unpublished dissertation. Argosy University.

Sayı, A. K. (2013). Farkılıaştırılmış Yabancı Dil Öğretiminin Üstün Zekalı Öğrencilerde Erişiye, Eleştirel Düşünmeye ve Yaratıcılığa Etkisi. Yayınlanmamış doktora tezi. İstanbul Üniversitesi.

Sondergeld, T. A. ve Schultz R. (2008). Science, Standards, and Differentiation: It Really Can Be Fun! Gifted Child Today, 31 (1), 34-40.

Sökmen, Y. (2013). Sınıf Öğretmeni Adaylarının Yürütücü Biliş, Düşünme Stilleri ve Akademik Başarıları Arasındaki Illişki. Yayınlanmamış yüksek lisans tezi. Atatürk Üniversitesi.

Stager, A. (2007). Differentiated Instruction in Mathematics. Unpublished master thesis. Caldwell College.

Sternberg, R. J. (1997). Thinking Styles. Cambridge: Cambridge University Press.

Sternberg, R. J. (2009). Düşünme Stilleri. (Çeviren: Esin Güngör). İstanbul: SEV Yayıncılık.

Sternberg, R. J. ve Zhang, L. F. (Eds.) (2001). Perspectives on Thinking, Learning, and Cognitive Styles. The Educational Psychology Series. Mahwah, NJ: Lawrence Erlbaum.

Sternberg, R. J. ve Zhang, L. F. (2005). Styles of Thinking as a Basis of Differentiated Instruction. Theory into Practice, 44 (3), 245-253.

Sternberg, R. J., Grigorenko, E. L. ve Zhang, L. F. (2008). Styles of Learning and Thinking Matter in Instruction and Assessment. Perspectives on Psychological Science, 3 (6), 486-506.

Suarez D. (2007). Differentiation by Challenge: Using A Tiered Program of Instruction in Mathmatics. In W. Powel and O. K. Powel (Eds.), Making the Difference: Differentiation in International Schools (pp. 199-227). Kuala Lumpur: EAF Press.

Subaşı, D. (2010). Öğrencilerin Öğrenme ve Düşünme Stillerinin Coğrafya Dersi Akademik Başarılarına Etkileri (12. Sınıf). Yayınlanmamış yüksek lisans tezi. Gazi Üniversitesi.

Şaldırak, B. (2012). Farkılış̧tııımış Öğretim Uygulamalarının Matematik Başarısına Etkisi. Yayınlanmamış yüksek lisans tezi. Ankara Üniversitesi.

Şenay, Ş. C. (2014). Matematik Öğretmen Adaylarının Sayılar Teorisine Yönelik Soyutlamayı Indirgeme Eğilimlerinin Düşünme Stilleri ve Matematik Öz Yeterlikleri ile ilişskisinin Incelenmesi. Yayınlanmamış doktora tezi. Marmara Üniversitesi.

Taş, F. (2013). Farklılaştııılmış Öğretim Tasarımının Öğrencilerin Bilişüstü Becerilerine ve Matematik Akademik Başarılarına Etkisi. Yayınlanmamış yüksek lisans tezi. Atatürk Üniversitesi.

Tomlinson, C. A. (1999). The Differentiated Classroom: Responding to the Needs of All Learners. Alexandria, VA: Association For Supervision and Curriculum Development.

Tomlinson, C. A. (2001). How to Differentiate Instruction in Mixed-Ability Classrooms. (2nd Ed.). Alexandria, VA: Association For Supervision And Curriculum Development.

Tunçer, B. K. (2013). Öğretmen Adaylarının Ilk Okuma Yazma Öğretimi Dersindeki Akademik Başarıları, Bilişüstü Farkındalık Düzeyleri, Düşünme Stilleri ve Tutumları Arasındaki Ilişkiler. Yayınlanmamış doktora tezi. Çanakkale Onsekiz Mart Üniversitesi. 
Turki, J. (2012). Thinking Styles "In Light Of Sternberg's Theory" Prevailing Among The Students of Tafila Technical University and its Relationship with Some Variables. American International Journal of Contemporary Research, 2 (3), 140-152.

Uğurlu, M. (2012). Ortaöğretim Kurumlarında Görev Yapan Öğretmenlerin Düşünme Stilleri ile Tükenmişlik Düzeyleri Arasındaki ilişkinin incelenmesi. Yayınlanmamış yüksek lisans tezi. Necmettin Erbakan Üniversitesi.

Umar, Ç. N. (2014). Karma Öğrenme Yöntemi ile Farklılaştırılmış Öğretim Ortamının Üstün Zekâlı ve Yetenekli Öğrencilerin Akademik Başarılarına, Eleştirel Düşünme Becerilerine ve Yaratıcılıklarına Etkisi. Yayınlanmamış doktora tezi. İstanbul Üniversitesi.

Üşenti, Ü. A. (2013). Üstün Zekalı ve Yetenekli Öğrencilere Uygulanan Farklılaştırılmış Türkçe Öğretim Uygulamalarının Etkinliğinin Sınanması. Yayınlanmamış doktora tezi. İstanbul Üniversitesi.

Xie, Q., Gao, X. ve King, R. B. (2013). Thinking Styles in Implicit and Explicit Learning. Learning and Individual Differences, 23, 267-271.

Yıldırım, A. ve Şimşek, H. (2011). Sosyal Bilimlerde Nitel Araştırma Yöntemleri (8. Baskı). Ankara: Seçkin Yayıncılık.

Yıldızlar, M. (2010). Farklı Kültürlerden Gelen Öğretmen Adaylarının Düşünme Stilleri. Hacettepe Üniversitesi Eğitim Fakültesi Dergisi, 39, 383-393.

Yılmaz, G. (2015). 9. Sınıf Öğrencileri için Kimyasal Türler Arası Etkileşimler Konusunda Öğrenme Istasyonlarının Geliştirilmesi ve Akademik Başarı Üzerindeki Etkisinin Incelenmesi. Yayınlanmamış yüksek lisans tezi. Dokuz Eylül Üniversitesi.

Yu, T. ve Chen, C. (2012). Thinking Styles and Preferred Teacher Interpersonal Behavior among Hong Kong Students. Learning and Individual Differences, 22, 554-559.

Yüksel, A. ve Avcı, S. (5-8 Ekim 2011). Farklılaştırılmış Öğretim Stratejileri ile Sosyal Bilgiler Dersinin İşlenmesi. I. Ulus/ararası Eğitim Programları ve Öğretim Kongresi. Anadolu Üniversitesi, Eskişehir.

Zhang, L. F. (2010). Do Thinking Styles Contribute to Metacognition beyond Self-Rated Abilities? Educational Psychology: An International Journal of Experimental Educational Psychology, 30 (4), 481-494.

Zhang, L. F. (2001). Do Thinking Styles Contribute to Academic Achievement beyond Self-Rated Abilities? Journal of Psychology, 135 (6), 621-637.

Zhang, L. F. (2002). Thinking Styles: Their Relationships with Modes of Thinking and Academic Performance. Educational Psychology, 22 (3), 331-348.

Zhang, L. F. (2003). Contributions of Thinking Styles to Critical Thinking Dispositions. The Journal of Psychology: Interdisciplinary and Applied, 137 (6), 517-544.

Zhang, L. F. (2004). Revisiting the Predictive Power of Thinking Styles for Academic Performance. Journal of Psychology, 138 (4), 351-370.

Zhang, L. F. (2008). Teachers' Styles of Thinking: An Exploratory Study. The Journal of Psychology: Interdisciplinary and Applied, 142 (1), 37-55.

Zhang, L. F. ve Sternberg, R. J. (2000). Are Learning Approaches and Thinking Styles Related? A Study in Two Chinese Populations. The Journal of Psychology, 134 (5), 469-489.

Zhu, C. (2013). Students' and Teachers' Thinking Styles and Preferred Teacher Interpersonal Behavior. The Journal of Educational Research, 106 (5), 399-407.

Zhu, C. ve Zhang, L. F. (2011). Thinking Styles and Conceptions of Creativity Among University Students. Educational Psychology: An International Journal of Experimental Educational Psychology 31 (3), 361-375. 


\section{Extended Summary}

The theory of thinking styles is based on mental self-government. The styles are similar to constructs of governments. Thinking styles are not skills, but they refer to the ways how to use skills. In other words, thinking style means what individuals prefer to do, and how they like to do it. Thinking styles fall into five dimensions, as functions, forms, levels, scopes and leanings. Functions of thinking styles are legislative, executive and judicial; forms of thinking styles are monarchic, hierarchic, oligarchic and anarchic; levels of thinking styles are local and global; scopes of thinking styles are internal and external; and leanings of thinking styles are liberal and conservative.

Differentiated instruction is an approach that helps teachers to plan strategically to meet the needs of all students. There are differences among learners, and the approach claims that teachers should take these differences into consideration while designing instruction. Teachers can differentiate content, process and product taking into account students' readiness levels, interests, and learning profiles. In the study, process was differentiated and students' thinking styles, a crucial element of learning profiles, were considered. Instructional strategies used in the study were stations, complex instruction, orbital studies, learning centers, entry points (narrational, foundational and experiential) and learning contracts.

Teaching process becomes more effective through style-differentiated instruction and teachers should differentiate instruction using thinking styles. At least, some of instruction should match students' styles of thinking. Therefore, students can maximally benefit from instruction and assessment. In other words, differentiating instruction in terms of students' thinking styles may provide students more effective learning environments. Furthermore, it may help them learn easily and permanently, and have positive attitude towards vocational foreign language course, language itself (English) and other foreign languages. The purpose of the study was to examine opinions of students about thinking-style-based differentiated instruction designed for the units "Booking a Hotel Room" and "Check-in and Check-out in a Hotel" in scope of vocational foreign language course at associate degree. Qualitative research method, case study and interview technique were used in the study.

Qualitative research method, case study and interview technique were used in the study. The study was carried out with 25 students studying at Tourism and Hotel Management Program and taking Vocational Foreign Language Course at 2014-2015 spring semester at a Vocational College. Process was differentiated in the study using stations, complex instruction, orbital studies, learning centers, entry points and learning contracts. The experimental study lasted 42 periods, during 7 weeks. After the experimental study, the students were asked to express their opinions about the process. An openended interview form was used to collect data. The interview forms were handed out to students they were asked to express their opinions in their own handwriting. The data were analyzed descriptively. Students' expressions were quoted directly to increase the validity.

It was found in the study that most of the students thought they learnt the two units. The main reason that helped them to learn was the instructional strategy used in the teaching-learning process. A few students declared that they did not learn the issues in the units because they did not attend the course regularly. Thinking-style-based differentiated instruction affected them positively because the activities helped them to develop vocabulary and to improve pronunciation. The instructional strategy helped them learn easily in that the activities made the course more enjoyable, they were more interested in and more motivated to the course, and they often participated in the course. Most of the students enjoyed the course, they felt happy, excited, relaxed, calm and at peace, they did not get bored and they participated in the course without anxiety. They indicated that they did not have any problems to be motivated in the course during the experimental study. They expressed that instructor's assistance and guidance was enough for them, which may be resulted from a well-designed instruction. A vast majority of the students indicated that they did not have any problems about the implementation of the experimental study. Consequently, students were satisfied with thinking-style-based differentiated instruction because all students participated in the courses, they watched videos, they acted out roleplays, they read, wrote, listened to dialogues and spoke during the courses and they learned better. 